\title{
Incidence of serum antibodies to native type I and type II collagens in patients with inflammatory arthritis
}

\author{
ROY B. CLAGUE, MARY J. SHAW, AND P. J. LENNOX HOLT \\ From the Department of Rheumatology, University of Manchester Medical School, Stopford Building, Oxford \\ Road, Manchester, M13 9PT
}

SUMMARY Using a new solid-phase double-antibody radioimmunoassay we have determined the incidence of serum IgG antibodies to native bovine type I and type II collagens in patients with rheumatoid arthritis (RA), ankylosing spondylitis (AS), and psoriatic arthritis. Raised serum IgG antibody levels to native type I collagen were present in $49 \%$ of patients with RA, $30 \%$ with AS, and none of the patients with psoriatic arthritis. Raised serum IgG antibody levels to native type II collagen were present in $42 \%$ of patients with RA, $30 \%$ with AS, and none of the patients with psoriatic arthritis. In rheumatoid arthritis there was a lack of correlation between IgG antibody levels to collagen and the erythrocyte sedimentation rate, IgG rheumatoid factor, and circulating immune complexes measured by the Clq-binding activity. In ankylosing spondylitis IgG antibody levels to native type II collagen were raised only in patients with peripheral joint involvement. The significance of IgG anticollagen antibodies is not certain, but parallels with rheumatoid factor are discussed.

The pathogenesis of the chronic inflammatory arthritides is unknown, though there are probably many processes involved. One hypothesis for the chronicity of these diseases is that type $\Pi$ collagen becomes an autoantigen (Steffen, 1970). Collagen antibodies have previously been demonstrated in the sera of patients with rheumatoid arthritis (RA) by the antiglobulin consumption test (Steffen and Timpl, 1963) or passive haemagglutination (Michaeli and Fudenberg, 1974a; Andriopoulos et al., 1976a). Collagen antibodies have also been detected in the synovial fluid of patients using passive haemagglutination (Cracchiolo et al., 1975; Andriopoulos et al., 1976b) and more recently a ${ }^{14} \mathrm{C}$-radioimmunoassay technique (Manzel et al., 1978).

We have developed a solid-phase double-antibody radioimmunoassay (Clague et al., 1979) for the detection of antibodies to collagen, and used this radioimmunoassay to determine the incidence of serum IgG antibodies to native type I and type II collagens in patients with RA, ankylosing spondylitis, and psoriatic arthritis.

Accepted for publication 30 April 1979 Correspondence to Dr R. B. Clague.

\section{Patients and methods}

\section{PATIENTS}

Forty-seven patients with definite or classical RA according to the criteria of the American Rheumatism Association, 20 with ankylosing spondylitis (Kellgren et al., 1963), and 14 with a seronegative polyarthritis associated with psoriasis (Wright, 1956) were studied. All patients were attending an outpatient clinic and taking their usual medications. The clinical details of these patients are summarised in Table 1. Forty blood donors were used as normal

Table 1 Clinical details of patients

\begin{tabular}{|c|c|c|c|c|c|}
\hline & & $\begin{array}{l}\text { Rheu- } \\
\text { matoid } \\
\text { arthritis }\end{array}$ & $\begin{array}{l}\text { Anky- } \\
\text { losing } \\
\text { spondy- } \\
\text { litis }\end{array}$ & $\begin{array}{l}\text { Psoriatic } \\
\text { arthritis }\end{array}$ & $\begin{array}{l}\text { Normal } \\
\text { controls }\end{array}$ \\
\hline \multirow{4}{*}{$\begin{array}{l}\text { Number } \\
\text { Female : male } \\
\text { Ages (years) } \\
\text { Disease duratior } \\
\quad \text { (years) } \\
\text { Erythrocyte } \\
\text { sedimentation } \\
\text { Rate } \\
\text { (mm/h) }\end{array}$} & & $\begin{array}{l}47 \\
25: 22 \\
36-77\end{array}$ & $\begin{array}{l}20 \\
5: 15 \\
19-50\end{array}$ & $\begin{array}{r}14 \\
5: 9 \\
19-59\end{array}$ & $\begin{array}{l}40 \\
25: 15 \\
18-65\end{array}$ \\
\hline & & $1-25$ & $1-20$ & $1-18$ & - \\
\hline & Mean & $37 \cdot 5$ & $32 \cdot 3$ & $19 \cdot 8$ & - \\
\hline & Range & $3-125$ & $2-97$ & $2-49$ & - \\
\hline
\end{tabular}


controls. Thirteen $(65 \%)$ of the patients with ankylosing spondylitis had peripheral joint involvement, and 3 patients had a previous history of uveitis.

\section{SERA}

Blood was taken at the outpatient clinic and allowed to clot at room temperature for 1-3 hours, centrifuged at $1500 \mathrm{~g}$ for 7 minutes, and the serum removed. The sera were divided into aliquots and stored at $-70^{\circ} \mathrm{C}$. Sera were thawed once only. Blood was also taken for routine investigations including the erythrocyte sedimentation rate (Westergren).

\section{COLLAGENS}

Acid-soluble native bovine type I collagen was extracted from fetal calf skin and purified by repeated salt and alcohol precipitation (Jackson and Cleary, 1967). Bovine type II collagen was extracted from articular cartilage by pepsin solubilisation following previous treatment with $2 \mathrm{M} \mathrm{MgCl}$ (Trelstad et al., 1977). The collagen type appeared pure on polyacrylamide gel electrophoresis. The collagen samples were lyophilised and stored at $-20^{\circ} \mathrm{C}$.

\section{IMMUNOCHEMICALS}

Rabbit antihuman IgG was obtained from Miles Laboratories. Human IgG was isolated from normal human pooled sera by DEAE-cellulose chromatography (Hudson and Hay, 1976). The human IgG was linked to cyanogen-bromide activated Sepharose 4B (Pharmacia), and this immunoabsorbent was used to separate specific antihuman IgG antibody. The antihuman IgG was eluted with $2.5 \mathrm{M}$ potassium thiocyanate, extensively dialysed against phosphate buffered saline (PBS), concentrated to $1 \mathrm{mg} / \mathrm{ml}$ in an Amicon Ultrafiltration unit, and stored at $-20^{\circ} \mathrm{C}$ in $1 \mathrm{ml}$ aliquots.

The antihuman IgG was labelled with ${ }^{125}$ I (Amersham Radiochemicals) to a specific activity of 0.5 $\mu \mathrm{Ci} / \mu \mathrm{g}$ by a modification of Hunter and Greenwood's (1962) method. Free ${ }^{125}$ I was removed from ${ }^{125}$ Ilabelled immunoglobulin using a Sephadex G25 (Pharmacia) column. The ${ }^{125} \mathrm{I}$-anti-human IgG was centrifuged at $20000 \mathrm{~g}$ for 40 minutes just before use to remove aggregates.

\section{RADIOIMMUNOASSAYS}

The radioimmunoassay was performed as previously described (Clague et al., 1979). Briefly, $25 \mu \mathrm{g}$ native collagen was incubated overnight at $4^{\circ} \mathrm{C}$ in $500 \mu \mathrm{l}$ $0.45 \mathrm{M} \mathrm{NaCl}, 0.02 \mathrm{M}$ Tris $\mathrm{pH} 7.5$ in unwashed new LP3 polystyrene tubes (Luckhams). The next day the tubes were washed 3 times with $1 \mathrm{ml}$ PBS at room temperature and then incubated at room temperature with $1 \mathrm{ml} 0.1 \%$ filtered bovine serum albumen (BSA) (Miles Laboratories) in PBS for 4 hours. Following a further 3 washings in PBS, $25 \mu \mathrm{l}$ serum was added in $500 \mu 10.1 \%$ BSA in PBS and incubated overnight at $4^{\circ} \mathrm{C}$. On the following day after washing 3 times in PBS, $1 \mu \mathrm{g}{ }^{125}$ I-antihuman IgG was added in $500 \mu 10.1 \%$ BSA in PBS and incubated at room temperature for 4 hours. After a final 3 washes in PBS the radioactivity bound to the tube was measured in an LKB Ultro gamma spectrometer. All sera were assayed in quadruplicate.

The total radioactivity added to the tube was also determined, as well as the amount of nonspecific binding of radioactivity to collagen coated tubes not containing any serum. The level of collagen antibodies ( $\mathrm{mg} / \mathrm{litre}$ ) was calculated as:

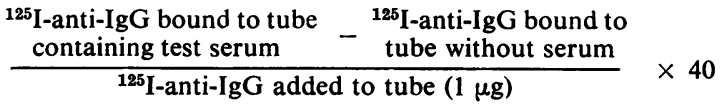

Thus the levels of antibodies to collagen were measured in terms of radioactive antihuman IgG specifically bound to the serum antibodies attached to the collagen on the surface of the tubes.

IgG rheumatoid factor was determined by the method of Hay et al. (1975), the upper limit of normal (mean $\pm 2 \mathrm{SD}$ ) being $0.374 \mathrm{mg} /$ litre. Circulating immune complexes were measured by the C1q binding activity (C1q-BA) (Zubler et al., 1976), the upper limit of normal (mean \pm 2 SD) was $5 \cdot 5 \%$.

Statistical analysis was carried out by the 2-tailed Mann-Whitney $U$ test and the Kendall rank correlation coefficient (tau) (Siegel, 1956).

\section{Results}

SER UM IgG ANTIBODIES TO NATIVE

BOVINE TYPE I COLLAGEN

The levels of serum IgG antibodies against native bovine type I collagen in the various groups of patients are shown in Fig. 1. The mean ( \pm 1 SD) of the normal controls was $0.69( \pm 0.195) \mathrm{mg} / \mathrm{l}$, giving an upper limit of $1.08 \mathrm{mg} / \mathrm{l}$ (mean $+2 \mathrm{SD}$ ).

The mean $( \pm 1 \mathrm{SD})$ in the patients with rheumatoid arthritis was $1 \cdot 14( \pm 0 \cdot 72) \mathrm{mg} /$ litre, and this difference from the normal controls was highly significant $(U=4 \cdot 57 \cdot 5, z=3 \cdot 98, P=0 \cdot 0002)$. The mean $( \pm 1$ SD) in the patients with ankylosing spondylitis was $0.87( \pm 0.53) \mathrm{mg} / \mathrm{l}$, and this was not significantly different from the normal controls $(\mathrm{U}=344, \mathrm{z}=0 \cdot 74, \mathrm{P}>0 \cdot 1, \mathrm{NS})$. The mean $( \pm 1 \mathrm{SD})$ in the patients with psoriatic arthritis was 0.56 $( \pm 0.265) \mathrm{mg} / \mathrm{l}$, which was not significantly different from the normal controls $(U=187 \cdot 5, z=1 \cdot 72$, $P=0.08$, NS).

Twenty-three (49\%) patients with RA, $6(30 \%)$ with ankylosing spondylitis and none $(0 \%)$ with 
psoriatic arthritis had elevated antibody levels to native bovine type I collagen.

\section{SER UM IgG ANTIBODIES TO NATIVE}

BOVINE TYPE II COLLAGEN

The levels of IgG antibodies against native bovine type II collagen are shown in Fig. 2. The mean $( \pm 1 \mathrm{SD})$ of the normal controls was $0.61( \pm 0.20)$

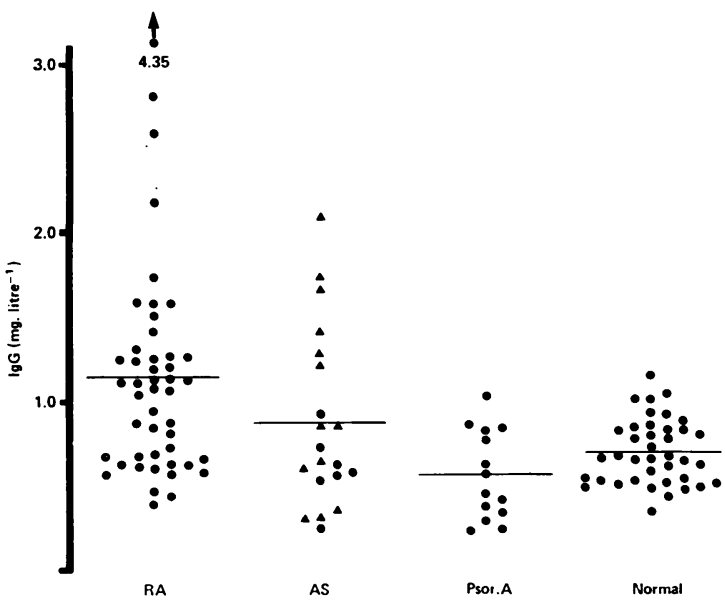

Fig. 1 Serum $\operatorname{Ig} G$ antibody levels to native bovine type I collagen in patients with rheumatoid arthritis $(R A)$, ankylosing spondylitis $(A S)$, psoriatic arthritis (Psor A), and normal controls. In AS group: $\Delta$ patients with peripheral arthritis, - patients with only spinal involvement

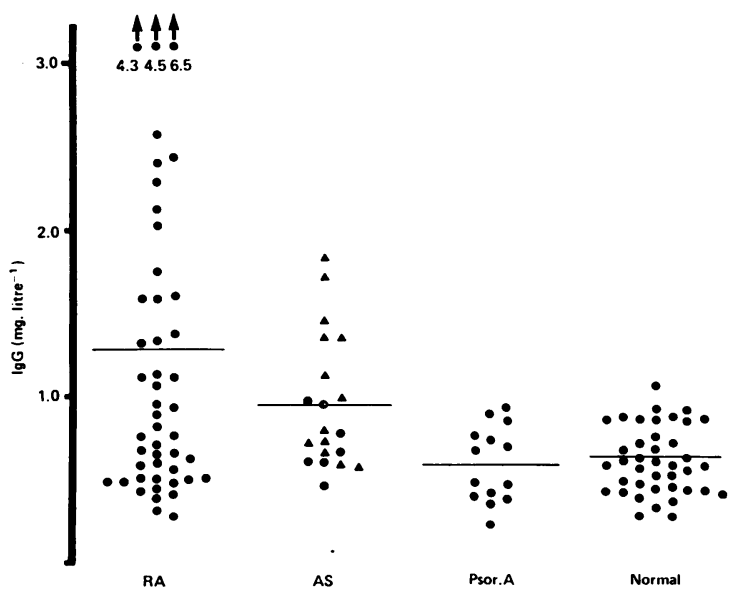

Fig. 2 Serum IgG antibody levels to native bovine type II collagen in patients with rheunatoid arthritis $(R A)$, ankylosing spondylitis $(A S)$, psoriatic arthritis (Psor $A)$ and normal controls. In AS group: $\Delta$ patients with peripheral arthritis, - patients with only spinal involvement $\mathrm{mg} / \mathrm{l}$, giving an upper limit of normal (mean $\pm 2 \mathrm{SD}$ ) of $1.01 \mathrm{mg} / \mathrm{l}$.

The mean $( \pm 1 \mathrm{SD})$ in the patients with rheumatoid arthritis was $1 \cdot 28( \pm 1 \cdot 21) \mathrm{mg} / \mathrm{l}$, and this difference from the normal controls was highly significant $(U=556 \cdot 5, z=3 \cdot 27, P=0.0015)$. The mean $( \pm 1 \mathrm{SD})$ in patients with ankylosing spondylitis was $0.945( \pm 0.40) \mathrm{mg} / \mathrm{l}$, and this difference from the normal controls was again highly significant $(\mathrm{U}=$ $179, z=3 \cdot 47, P=0 \cdot 0009$ ). The patients with psoriatic arthritis had a mean level of $0.59( \pm 0.23)$ $\mathrm{mg} / \mathrm{l}$, which was not significantly different from the normal controls $(U=266, z=0 \cdot 28, P>0 \cdot 1$, NS $)$.

Twenty $(42.5 \%)$ of the rheumatoid patients, $6(30 \%)$ with ankylosing spondylitis, and none with psoriatic arthritis had elevated antibody levels to native bovine type II collagen.

\section{RHEUMATOID ARTHRITIS}

Twenty-seven $(57.4 \%)$ patients with RA had increased serum IgG antibody levels to either or both native bovine type I and type II collagens. There was a significant correlation $(\tau=0 \cdot 468, z=4 \cdot 64, P=$ 0.00006 ) between serum IgG antibody levels to type I and type II collagens (Fig. 3). However, there were 2 patients with extremely high levels of serum IgG antibody levels to native type II collagen who had normal or only slightly raised levels to native type I collagen.

There was a lack of correlation between serum IgG antibody levels to native collagen and clinical activity as measured by the erythrocyte sedimentation rate (Fig. 4 -results shown only for native type II collagen) (type I against ESR: $\tau=0.031, z=$ $0 \cdot 305, \mathrm{P}>0 \cdot 1$, NS; type $\Pi$ against ESR : $\tau=0 \cdot 043$,

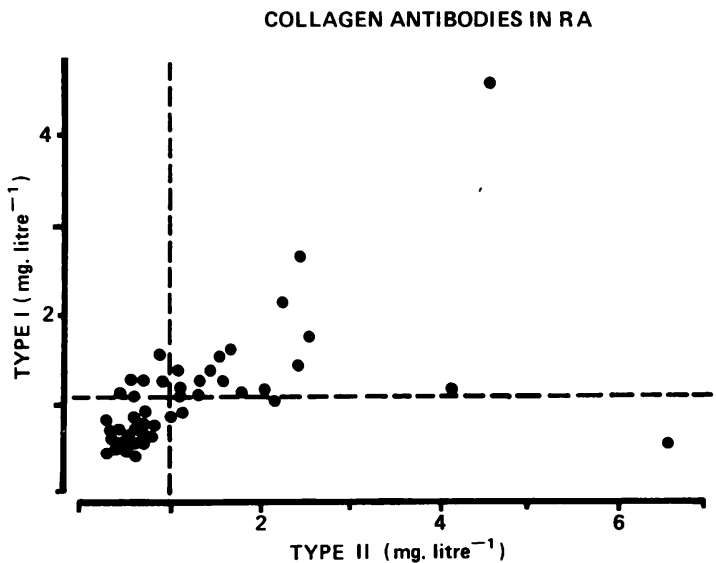

Fig. 3 Correlation between serum IgG antibody levels to native bovine type I and type II collagens in 47 patients nith rheumatoid arthritis. Dotted lines indicate upper limits of normal. 
$z=0.424, P>0.1, N S)$. There was also a lack of correlation with the level of $\mathrm{IgG}$ rheumatoid factor (Fig. 5) (type I against IgG Rh factor: $\tau=0 \cdot 159$, $\mathrm{Z}=1 \cdot 50, \mathrm{P}>0 \cdot 1$, NS; type II against IgG $\mathbf{R h}$

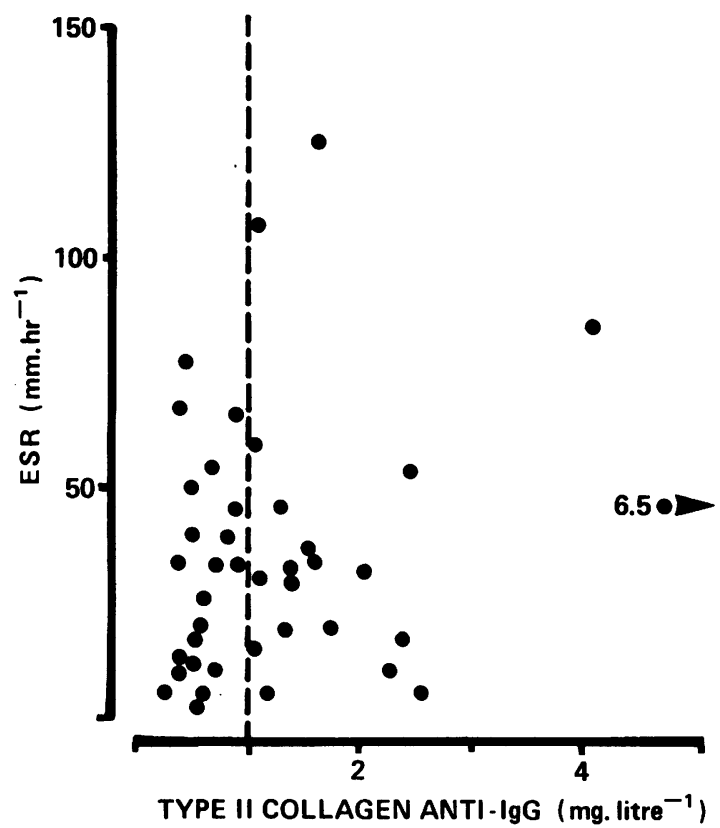

Fig. 4 Erythrocyte sedimentation rate plotted against serum IgG antibody levels to native bovine type II collagen in 47 patients with rheumatoid arthritis. Dotted line indicates upper limit of normal.

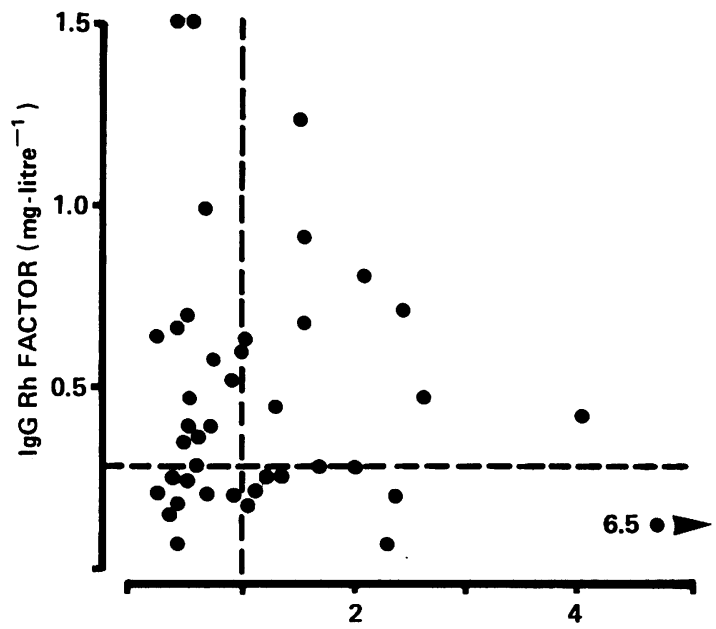

TYPE II COLLAGEN ANTI-IgG ( $\mathrm{mg}_{\text {-litre }}{ }^{-1}$ )

Fig. 5 Serum IgG rheumatoid factor plotted against serum IgG antibody levels to native bovine type II collagen in 47 patients with rheumatoid arthritis. Dotted lines indicate upper limits of normal. factor: $\tau=0, z=0, P>0 \cdot 1, N S)$. It can be seen that there were patients with high serum IgG antibody levels to native bovine type II collagen who had normal levels of IgG rheumatoid factor, and viceversa. Fig. 6 shows the lack of correlation between serum IgG antibody levels to native type II collagen and circulating immune complexes measured by the ${ }^{125} \mathrm{I}-\mathrm{C} 1 \mathrm{q}$ binding activity (type I against $\mathrm{Clq}$ BA: $\tau=0.007, z=0.07, P>0.1, N S ;$ type $\Pi$ against C1q BA: $\tau=0 \cdot 11, \mathrm{z}=1 \cdot 09, \mathrm{P}>0 \cdot 1, \mathrm{NS})$.

\section{ANKYLOSING SPONDYLITIS (AS)}

Seven (35\%) patients with AS had raised serum IgG antibody levels to either or both native type I and type II collagens. All six patients with elevated levels to native type $\Pi$ collagen had peripheral joint involvement, and the 7 patients with only spinal involvement had normal levels to native type II collagen. The 3 patients with a previous history of uveitis did not have raised serum IgG antibody levels to native type II collagen. However, the patient with recent uveitis (onset 10 days earlier) had an elevated serum IgG antibody level $(1.27 \mathrm{mg} / \mathrm{l})$ to native type I collagen, but this fell to normal levels

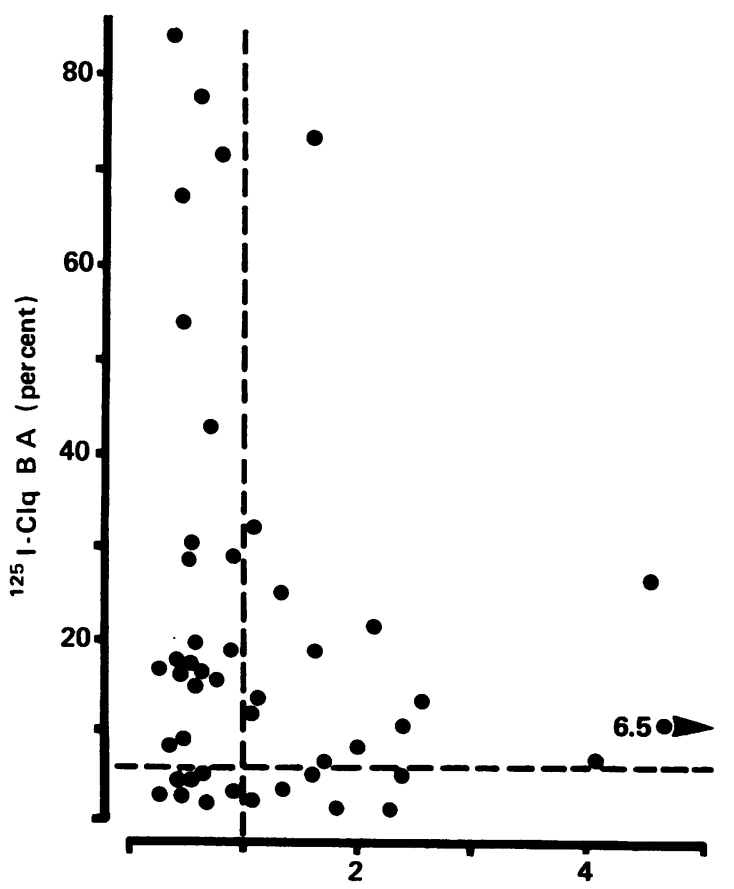

TYPE II COLLAGEN ANTI-IgG ( $\mathrm{mg}$ - litre ${ }^{-1}$ )

Fig. 6 Cla binding activity plotted against serum IgG antibody levels to native bovine type II collagen in 47 patients with rheumatoid arthritis. Dotted lined indicate upper limits of normal. 
3 months later. This patient had no peripheral joint involvement.

\section{Discussion}

Antibodies to collagen have been detected in the sera of patients with RA by the antiglobulin consumption test (Steffen and Timpl, 1963) or the passive haemagglutination test (Michaeli et al., 1974a; Andriopoulos et al., 1976a). These tests are relatively insensitive and do not measure class-specific immunoglobulin. We have used a new solid-phase radio immunoassay for the detection of IgG antibodies to collagen in human sera, which has been verified with antisera to collagen raised in rabbits and rats (Clague et al., 1979). It has the advantages that it is a highly sensitive assay which allows the accurate determination of the incidence of class-specific immunoglobulins to collagen and that unlike the ${ }^{14} \mathrm{C}$-radioimmunoassay technique (Menzel et al., 1978) the collagen molecule is not labelled and so its antigenicity is unaffected.

In our studies we have used native bovine collagens because of the known immunological crossreactivity between human and bovine collagens (Furthmayr and Timpl, 1976), which was confirmed by the radioimmunoassay (Table 2). Another factor was the ease, as compared with human material, in obtaining a good supply of bovine tissue from which to extract and purify the collagen types.

Only low levels of serum IgG antibody to native type I and type II collagen were found in our normal controls. Twenty-three (49\%) patients with RA had raised serum IgG antibody levels to native type I collagen and $20(42 \cdot 5 \%)$ to native type II collagen. This incidence is lower than that found by Andriopoulos et al. (1976a), who showed the presence of antibodies to native type I and type II collagens in $77 \%$ and $71 \%$ patients with $\mathrm{RA}$ respectively. This discrepancy may be related to differences in immunoglobulin class, as we were detecting only IgG antibody, or the use of different techniques for estimation, or differences in case selection. Human serum IgG antibody levels to type II collagen are relatively low when compared to the IgG antibody levels in experimental animals immunised with native collagen (Claque et al., 1979; Morgan et al., in press).

Table 2 Cross-reactivity (per cent) to human collagens of rabbit antibodies to bovine collagens

\begin{tabular}{lll}
\hline Rabbit Antisera to: & & \\
Acid-soluble & Bovine type I & Human type I \\
Bovine type I & 100 & 108 \\
Pepsin-soluble & Bovine type II & Human type II \\
Bovine type II & 100 & 106 \\
\hline
\end{tabular}

There was a significant correlation between the serum IgG antibody levels to native type I and type II collagens. This suggests immunity to components of more than one tissue in rheumatoid disease, as type I collagen is found in the skin, synovium, capsule, and bone, whereas type II collagen is found in articular cartilage (Martin et al., 1975). Two patients, however, had extremely high levels to native type II collagen with normal or slightly elevated levels to native type I collagen and were different in this respect from the majority. This aspect may be of clinical significance and is being investigated further.

As in previous studies (Michaeli and Fudenberg, 1974a; Andriopoulos et al., 1976a), we have failed to show a correlation of antibodies to type I and type $\Pi$ collagen with clinical activity as measured by the ESR or IgG rheumatoid factor. We have looked especially at IgG antiglobulins (rheumatoid factor) since we were measuring serum IgG antibody to native collagens. It is interesting that some patients have high levels of either serum IgG antibody to native collagens or of IgG antiglobulins with normal levels to the other antigen. This suggests there are different subsets of patients which may be of clinical significance and require further study.

There was also a lack of correlation with the level of circulating immune complexes measured by the C1q-BA. C1q is a subcomponent of the first component of human complement and is known to contain a collagenous sequence in its structure (Reid and Porter, 1976). Immune complexes have been demonstrated in the articular collagenous tissue of patients with RA (Cooke et al., 1975), and one possible explanation for the presence of immune complexes in cartilage could be binding to collagen through the same receptor as for C1q Our studies, however, suggest that circulating immune complexes do not bind to native collagen in a similar manner as their binding to C1q.

Although the highest serum IgG antibody levels to native collagens were present in patients with rheumatoid arthritis, serum IgG antibodies to native type I and type II collagens were also found in patients with ankylosing spondylitis. Raised levels of IgG antibody to native type II collagen were only present when there was peripheral joint involvement. None of the 3 patients with a previous history of uveitis had a raised IgG antibody to native type II collagen, though one patient had an elevated level to native type I collagen.

None of the patients with psoriatic arthritis had elevated serum IgG antibody levels to native type I or type $\Pi$ collagen. These patients had less severe disease than the patients with rheumatoid arthritis or ankylosing spondylitis (see Table 1), and this could explain the difference between these groups. 
There is also little evidence of immunological abnormalities in psoriatic arthritis (Wright, 1978), so that antibodies to collagen may not be expected.

The significance of serum IgG antibodies to native type $I$ and type $I I$ collagens is not clear. The finding of a correlation between serum IgG antibody levels to native type $\Pi$ collagen and the presence of arthritis (Morgan et al., 1979) in rats with native type II collagen-induced arthritis (Trentham et al., 1977) is interesting. However, the lack of correlation with disease activity in patients and the lack of collagen antibodies in adjuvant disease of rats (personal observations) all suggest that collagen antibodies may not be directly associated with the pathogenesis of arthritis. The parallel with rheumatoid factor (antiglobulin) is apparent; it is present in the normal population, in other types of arthritis, and in nonarticular diseases, and rheumatoid disease may occur without elevated levels. Serum IgG antibodies to the collagens may be present in other types of arthritis, in nonarticular diseases (Michaeli and Fudenberg, 1974b) and rheumatoid disease may occur without elevated levels. Further studies are now in progress to determine the significance and origin of elevated antibody levels to collagen in the chronic arthritides.

We thank Mrs D. Ward for typing the manuscript, Mrs S. Roe (Department of Medical Illustrations) for preparing the figures, and Miss Linda Hunt (Faculty of Medicine Computational Group) for statistical analysis.

Dr R. B. Clague was in receipt of a Medical Research Council training fellowship and the work was also supported by the Arthritis and Rheumatism Council and the Northwest Regional Area Health Authority.

\section{References}

Andriopoulos, N. A., Mestecky, J., Miller, E. J., and Bradley, E. L. (1976a). Antibodies to native and denatured collagens in sera of patients with rheumatoid arthritis. Arthritis and Rheumatism, 19, 613-617.

Andriopoulos, N. A., Mestecky, J., Miller, E. J., and Bennett, J. C. (1976b). Antibodies to human nature and denatured collagens in synovial fluids of patients with rheumatoid arthritis. Clinical Immunology and Immunopathology, 6, 209-212.

Clague, R. B., Brown, R., Weiss, J. B., and Holt, P. J. L. (1979). Solid-phase radioimmunoassay for the detection of antibodies to collagen. Journal of Immunological Methods, 27, 31-41.

Cooke, T. D., Hurd, E. R., Jasin, H. E., Bienenstock, J., and Ziff, M. (1975). Identification of immunoglobulins and complement in rheumatoid articular collagenous tissues. Arthritis and Rheumatism, 18, 541-551.

Cracchiolo, A., Michaeli, D., Goldberg, I. S., and Fudenberg, H. H. (1975). The occurrence of antibodies to collagen in synovial fluids. Clinical Immunology and Immunopathology, $3,567-574$.
Furthmayr, H., and Timpl, R. (1976). Immunochemistry of collagens and procollagens. International Review of Connective Tissue, 7, 61-99.

Hay, F. C., Nineham, L. J., and Roitt, I. M. (1975). Routine assay for detection of IgG and IgM antiglobulins in seronegative and seropositive rheumatoid arthritis. British Medical Journal, 3, 203-204.

Hudson, L., and Hay, F. C. (1976). Practical Immunology, Blackwell Scientific Publications: Oxford.

Hunter, W. M., and Greenwood, F. C. (1962). Preparation of iodine-131 labelled human growth hormone of high specific activity. Nature, 194, 495-496.

Jackson, D. S., and Cleary, E. G. (1967). Methods of Biochemical Analysis, Vol. 15, p. 32. Edited by D. Glick. Interscience Publishers: London.

Kellgren, J. H., Jeffrey, M. R., and Ball, J. (Eds.) (1963). The Epidemiology of Chronic Rheumatism, Vol. 1., p. 326. Blackwell: Oxford.

Martin, G. R., Byers, P. H., and Piez, K. A. (1975). Procollagen. Advances in Enzymology, 42, 167-191.

Menzel, J., Steffen, C., Kolarz, G., Kojer, M., and Smolen, J. (1978). Demonstration of anticollagen antibodies in rheumatoid arthritis synovial fluids by ${ }^{14} \mathrm{C}$-radioimmunoassay. Arthritis and Rheumatism, 21, 243-248.

Michaeli, D., and Fudenberg, H. H. (1974a). The incidence and antigenic specificity of antibodies against denatured human collagen in rheumatoid arthritis. Clinical Immunology and Immunopathology, 2, 153-159.

Michaeli, D., and Fudenberg, H. H. (1974b). Antibodies to collagen in patients with emphysema. Clinical Immunology' and Immunopathology, 3, 187-192.

Morgan, K., Clague, R. B., Shaw, M. J., and Holt, P. J. L. (In press). Native type II collagen-induced arthritis in the rat 1 . Incidence and humoral response to collagen.

Reid, K. B. M., and Porter, R. R. (1976). Subunit composition and structure of subcomponent $\mathrm{Clq}$ of the first component of human complement. Biochemical Journal, 155, 19-23.

Siegel, S. (1956). Non-parametric statistics for the behavioural sciences. McGraw-Hill: London.

Steffen, C. (1970). Consideration of rheumatoid arthritis as collagen autoimmunity. Zeitschrift für Immunitäts- und Allergieforschung, 139, 219-227.

Steffen, C., and Timpl, R. (1963). Antigenicity of collagen and its application in the serologic investigation of rheumatoid arthritis sera. International Archives of Allergy and Applied Immunology, 22, 333-349.

Trelstad, R. L. Rubin, D.. and Gross, J. (1977). Osteogenesis imperfecta congenita: evidence for a generalised molecular disorder of collagen. Laboratory Investigation, 36, 501-508.

Trentham, D. E., Townes, A. S., and Kang, A. H. (1977). Autoimmunity to type II collagen: an experimental model of arthritis. Journal of Experimental Medicine, 146, 857868.

Wright, V. (1956). Psoriasis and arthritis. Annals of the Rheumatic Diseases, 15, 348-356.

Wright, V. (1978). Psoriatic arthritis. In Copeman's Textbook of Rheumatic Diseases, 5th edn., p. 537. Edited by J. T. Scott. Churchill Livingstone: Edinburgh.

Zubler, R. H., Nydegger. U., Perrin, L. H., and Fehr, K. (1976). Circulating and intra-articular immune complexes in patients with rheumatoid arthritis. Journal of Clinical Investigation, 57, 1308-1319. 